\title{
The "Gift" Concept in the Individual Consciousness of the Chinese and Russians
}

\author{
Anna A. Vasil'eva* and Olga V. Chibisova \\ Komsomolsk-on-Amur State University \\ 27 Lenin, Komsomolsk-on-Amur, 681013, Russia
}

Received 01.09.2017, received in revised form 04.12.2017, accepted 14.12.2017

\begin{abstract}
The article is in the context of sociolinguistic and linguocultural researches related to theoretical and empirical issues of comprehensive study of concepts. It stands in the gap of such researches as it examines the "gift" concept which is not reflected in the currently existing works. The gift is a very important part of social interaction both in business and everyday life. The deepening cooperation between Russia and China put forward the study of the Russian and Chinese mentality and culture that have practical importance for many professionals, involved in the orbit of Russian-Chinese cooperation. This article offers a comparative analysis of the Russian and Chinese associations related to the "gift" concept, which reveals the universal and the national in their semantics. The knowledge of these features will enable communicants to overcome the barriers of misunderstanding.
\end{abstract}

Keywords: concept, gift, social and intercultural communication.

DOI: 10.17516/1997-1370-0197.

Research area: psychology.

\section{Introduction}

A gift is a very important attribute of communication both in business and everyday life. It is one of the main categories that have universal characteristics and national-specific ones as well. The comparison of its implementation in the Russian and Chinese cultures on different blocks of materials can help to identify these features. Against the background of rapidly developing international relations between Russia and China, the study of notions, entrenched in the minds of the Chinese and Russians is essential for forming a better opinion of the target cultures, national characters and language picture of the world. In addition a small number of scientific works in the field of studying this concept confirms the relevance of this work.

The first use of term "concept" in the Russian science is found in an article by S.A. Askol'dov "The word and concept" (1997). The term has gained recognition since the $90 \mathrm{~s}$ of the $20^{\text {th }}$ century, largely due to the scientific works of D.S. Likhachev (1993) and J.S. Stepanov (2007), who resuscitated it and offered their own detailed interpretation of it. Askol'dov defined "concept" as a mental formation which replaces in the process of thinking an indefinite multitude of objects, actions, mental functions of the same kind. Likhachev believes that the concept does not arise from the meaning of words; it is a result

(C) Siberian Federal University. All rights reserved

* Corresponding author E-mail address: anna_the_first@mail.ru 
of a collision of the mastered meaning with the speaker's personal experience. For Stepanov the concept is like a clot of culture in the human mind; something with which a culture is included in human mental world.

The most widely known fundamental researches in the field of concepts are the works of V.I. Karasik, G.G. Slyshkin and I.A. Sternin (Karasik, 2001). The scientists define a concept as a standard unit of mentality, aimed at the integrated study of language, culture and consciousness. In their view, the concept is grouped around the valuably accentuated point of consciousness, out of which come associative vectors. The core of a concept is the brightest associations of the native speakers. Less significant associations form the periphery; moving away from the nucleus, the associations fade. The specific concept borders are not defined.

Among the recent studies of concepts there are researches pursued by R.N. Chikogu (2009), N.A. Gunina (2011), $\quad$ E. Türkey (2013), M. Kysylbaikova (2014), L. Manerko (2014), A. Biyazdykova, T. Nurpeiys and M. Baimuhanbetova (2014), Z. Kövecses (2015), A.A. Tovbaz and O.V. Chibisova (2012). Their attempts to apprehend the essence of the concept result in a number of the various points of view. Yet they all agree that the dual nature of the concept allows considering it both as a unit of cognitive level and a phenomenon of culture. The content of the concepts is socio-culturally determined and as such it different for different peoples and periods of time. Since the beginning of studying concepts, the linguistic science has become closer to human thinking, goals of communication and purposes of language teaching. According to K.A. Kardash (2016), the correct perception of the national identity makes different cultures closer to and more respectful of each other.

After analyzing the existing points of view on the problem of concepts, one can conclude that the most frequently used methods are the analysis of lexical paradigms verbalizing the concept, the analysis of proverbs and aphorisms, the lexical analysis of words representing the concept, associative and receptive experiments. In this paper, the study of the "gift" concept is made through the use of such methods as associative experiment and questionnaires.

\section{Object and subject of research}

The object of research is a "gift" concept in China and Russia. The subject of research is its ethnocultural characteristics in the Chinese and Russian individual consciousness.

The Chinese concept of "gift" is verbalized by a sign 礼物 (present; offering; gift; tribute). Separately the character 礼 denotes a gift, courtesy, etiquette. In combination with other characters it has the following interpretation: a polite welcome, courteous attitude, manners, and politeness. In turn, as follows from http:// www.trainchinese.com/v1/a_user/index.php, the character 物 means "a thing, an object". Thus, one can conclude that the Chinese gift is a peculiar act of courtesy. The Electronic Dictionary of the Chinese Language on http:// xh.5156edu.com/htm15/297760.html gives the following interpretation of the character 礼物: the thing presented in order to show respect or congratulate, in a general sense it is the thing that is presented. According to the dictionary in the resource http://www.zdic.net/c/c/151/335995.htm, 礼物 is interpreted as the thing presented to a person; the thing given on a holiday with friendly intentions. The site http://baike.baidu.com/ subview/54278/6478972.htm gives the following definition: in the social sense "gifts" are things that people exchange in order to express their thoughts, wishes and show friendly intentions. The analysis of these entries shows that all interpretations agree that the word "gift" in the Chinese refers to an object that is presented and 
the purpose of donation is to pay tribute, to show good or friendly intentions.

In Russian, according to the Ozhegov's explanatory dictionary on http://www.ozhegov. com/words/24006.shtml, a gift is a thing which is presented or was presented; something good, pleasant (usually as a sign of respect, appreciation); a great and unexpected good luck, joy. The dictionary on the resource: http://www. gramota.ru/slovari/dic/?word gives the following definitions: something which is presented or was presented; something that affords pleasure or pleases; not a gift is someone or something that none too good (no sugar). According to http:// ushakovdictionary.ru/word., a gift is an object or thing which is voluntarily gratuitously given, presented, donated to someone for the purpose of pleasing, benefiting; the object, occurrence which afforded an unexpected pleasure. So, for the Russians, a gift is something which is presented. It is also important that it mustn't be material; it may be a joyful event or something pleasant.

Comparing the dictionary meaning of "gift" concept in Russian and Chinese, one can detect some similarities and differences. In both languages it was noted that the gift is a thing presented as a donation. However, in China they make it to pay tribute, to show good or friendly intentions, and in Russia the goals are different (to please, to benefit). Besides in the Russian language the word "gift" has a number of figurative meanings which it does not have in Chinese.

For the more accurate representation of the "gift" concept in China and Russia it is interesting to read the analysis of the Chinese and Russian proverbs which can be found in the work "Semantic variability of the "gift" concept in the Chinese and Russian lingvocultures" (Vasil'eva, Chibisova, 2015). Still, it should be borne in mind that ordinary consciousness, keeping the experience of previous generations, however, adapts it to the new conditions.

\section{Materials and procedures}

For defining the content of the "gift" concept in the individual consciousness of the modern Chinese and Russians, the following questionnaire was used. The first part of it is based on the free association and requires answers reflecting the existing relationships of objects in reality and establishing new relations on the basis of which the object recognition processes.

\section{Part 1}

1. What associations does the word "gift" bring to you?

2. What gift you've ever received do you consider the most valuable? Why?

3. What gift you've ever given do you consider the best? Why?

4. What are the three gifts that are most common in your country?

5. What kind of gift would you give to your Chinese (Russian) friend? Why?

The second part of the questionnaire is different for the Chinese and the Russians as it acquires the knowledge of the compared cultures. It represents the question with multiple answers to choose from. The questions were aimed at identifying the specific cultural characteristics and the probability of the failure of cross-cultural communication.

\section{Part 2 (for the Russians)}

1. What kind of flowers would you present on birthday to your friend from China?

a) roses;

b) gladioli;

c) chrysanthemums.

2. How will a Chinese react if you give him/her an umbrella?

a) will be glad, because umbrella in China means protection from evil spirits; 
b) will be upset because umbrella means separation.

3. What gift would you give to your Chinese friend on the New Year?

a) a set of knives;

b) a live orange tree;

c) 400 yuan in a red envelope.

Part 2 (for the Chinese)

1. What kind of flowers would you present on birthday to your friend from Russia?

a) 5 white roses;

b) 2 carnations;

c) 4 chrysanthemums.

2. What kind of gift you would give to a friend from Russia?

a) a handkerchief;

b) a wallet (money);

c) a wristwatch.

3. If you cannot come to a friend's birthday in Russia, you will:

a) give a gift in advance before your departure;

b) give a gift on your return to Russia.

During the survey there were interviewed 40 representatives of the Chinese and 40 representatives of the Russian linguocultures. They were the Russian and Chinese students from Komsomolsk-on-Amur State Technical University and the Pacific State University of Khabarovsk. Gender differences were not taken into account, the time was not limited.

\section{Analysis result}

This section considers the reflection of a "gift" concept in the individual consciousness of modern Chinese and Russians. The main methods used to solve this problem are the method of free association experiment and questionnaires.

In the first part of the questionnaire, the respondents were asked to name their associations to the word "gift". Among the responses of Chinese responders, the most frequently mentioned were the following: "give a gift" which is $9 \%$ of all the answers; "feelings" and "a pleasant surprise" which also account for $9 \%$. The answers "birthday", "friendship" and "happiness" form up to $7 \%$ of all responses. The respondents also named such associations as "meeting with friends", "apology", "wedding ceremony”, "St. Valentine's Day", "Christmas", "respect", "a request for a favor", "mutual gifts", "profit", "benefit", "generosity", "waste of money", "impatience", "importance" and "attention". These variations account for approximately $4 \%$ of the total responses.

Thus, all the associations can be grouped into:

1) celebrations (birthday, wedding ceremony, St. Valentine's Day, Christmas);

2) feelings (apology, respect, friendship, happiness, generosity, a pleasant surprise, impatience, importance and attention);

3) selfish intention (request for a favor, mutual gifts, profit, benefits);

4) negative associations (expense);

5) other associations (give a gift, meeting with friends).

As it turned out, a group "celebrations" includes $19 \%$ of the total responses, a group "feelings" $-56 \%$, the group "selfish intentions"$12 \%$, "negative associations" $-4 \%$, and the group of "other associations" - $9 \%$. Thus, it is obvious that the Chinese value most the emotional side of the gift.

Among the responses of the Russians, of the most frequency were "joy" which is about $29 \%$ of the total responses, and "holiday" $-9.2 \%$. Less frequently were mentioned "attention" (6.5\%), "surprise" (5.2\%), "whole-heartedly" (5.2 \%). Then came "package", "something bright, brilliant" and "warmth, good" making up $4 \%$ of the total amount of responses. Besides there were mentioned "nice necessary thing", "smile", "new thing", "expense" and 
"excitement" forming $2.6 \%$ each, as well as "Christmas", "New Year", "birthday", "miracle", "wish-fulfillment" "expensive thing", "dance", "interest", "recollection", "guilt", "boredom", "irritation", "work", "book", "flowers" each forming $1.3 \%$ of the total sum of the responses.

Again, to present a clearer picture, all the associations were divided into the following groups:

1) celebrations (birthday, Christmas, New Year);

2) feelings (attention, joy, smile, surprise, warmth and good, excitement, interest, recollection);

3) gift description (package, nice necessary thing, something bright and brilliant, expensive thing, new thing, book and flowers);

4) negative associations (expense, guilt, boredom, annoyance);

5) other associations (miracles, dreams, dance and work).

The group "celebrations" is $14 \%$ of the total sum of the responses while the groups "feelings", "gift description", "negative associations" and "other associations" are $58 \%, 15 \%, 7 \%$ and $6 \%$, respectively.

Thus, it becomes obvious that in the minds of individual members of Russia emotional aspect of "gift" concept is very important; it is also true for the Chinese. The association experiment confirmed that the concept of "gift" has mainly positive connotations. However, it is important to note that both the Chinese and the Russians named negative associations (4\% and $7 \%$, respectively).

According to the Chinese respondents, a book is the best gift they have ever received, which represents about $30 \%$ of the total amount of responses. Slightly less important are such answers as wristwatches and any gift from a friend, $13 \%$ each choice. Answers "computer" and "mug" are up to $8 \%$ of the total responses and options for "life", "money", "education", "hand-made gift", "skirt" and "erotic gift" are $4 \%$ each. An interesting fact is that among the reasons why this gift is considered the best, most respondents mentioned the donor. The analysis of the answers makes it possible to conclude that for the Chinese the material value of the present is less important than a person from whom the gift was received.

Most of the asked Russians (20\%) had difficulty in answering what kind of gift they ever received was the best one because of several reasons: all gifts are equally good, attention is more important than gift, etc. $10 \%$ believed that the best gift is the one that is remembered and $7.5 \%$ preferred hand-made gifts. The rest answers can be divided into two categories: material and non-material gifts. The material gifts include music CDs (5\%), speakers (2.5\%), money (2.5\%), a book (7.5\%), a dog (2.5\%), the right gift $(2.5 \%)$, a flower in a pot (5\%), a chocolate bar (2.5\%), a portrait (2.5\%), a shaving machine $(2.5 \%)$, a vehicle $(2.5 \%)$, and a mobile phone $(2.5 \%)$. The category of non-material gifts includes attention (5\%), an inscription on the pavement under the window (2.5\%), gifts of fate $(2.5 \%)$, sister/brother (5\%) and life (2.5\%). Among the reasons for choosing these gifts most often there was mentioned the attitude to the donor, the feeling caused by this gift and the necessity of the gift.

The comparative analysis of the responses of respondents in both countries indicated that both the Russians and the Chinese appreciate a gift according to the feelings it evokes. They highly evaluate gifts made by the donator with his/ her own hands as they mean care and attention. However, the Russian respondents mentioned the practicality of the gift which is absent in the Chinese replies. A book is thought the best present by many Chinese respondents while only $7.5 \%$ of the Russians agree with it. This fact is 
of certain interest because not so long ago in the former Soviet Union presenting a book was widespread and appreciated.

According to the Chinese, the best gift they ever made are flowers, a book, a card made with their own hands, the gift liked by their friend and gifts made with their own hands, which are $50 \%$ of the total responses, $10 \%$ each, respectively. Such options as a marriage proposal, a gem, tea, china, love, money, a digital photo frame, a phone, a wristwatch and a photograph form $5 \%$ each, which is $50 \%$ of $100 \%$. The analysis of the responses to this question once again confirms the correctness of the conclusion that in China, the material side of the "gift" concept is less important than the emotional.

In turn, the majority of the Russians found it difficult to say what gift ever donated by them can be considered the best (28.9\%) because they believe that all the gifts are equally good. $23.6 \%$ of respondents believe the best gift to be a product made with their own hands. Highly valued are such gifts as money (15.7\%), love, attention (10.5\%) and jewelry (7.8\%). There were also mentioned flowers $(5.2 \%)$, the desired gifts (5.2\%) and spirits (2.6\%). These responses suggest that the Russians value not a gift as such, but the emotions and feelings which it causes (love, care, attention), the same as in the case with the Chinese. It is worth mentioning that the Chinese people listed a lot more material gifts than the Russians.

According to the survey, the most popular gifts for the Chinese are the flowers $(14 \%$ of the total responses), tea (12.6\%), spirits $(9.5 \%)$, and the money (9.5\%). Indeed, in China they are very sensitive to such a gift as flowers. Each flower has its own meaning, so that the bouquet becomes a kind of a message that expresses the attitude of the giver to the endowed person or kind wishes to him. Flowers in China are a suitable gift not only for women but also for men. Money is also a very symbolic gift. According to ancient beliefs, the money donated to the red envelope brings wealth and prosperity to the endowed person. In addition, it is believed that the donated amount will return to the donor threefold. The next most popular gifts are chocolate (6\%), food (5\%), clothing (5\%), and a lighter (5\%). They are followed by decorations (3\%), a mug (3\%), a wristwatch (3\%), fruits (3\%), Chinese knot (a talisman for good luck) (3\%), a photo frame, jade goods, a book, a car, a postcard, pearls and toys which accounted to $1.5 \%$ of the total amount of responses.

Thus, it can be considered as another confirmation of the fact that the "gift" concept in the Chinese culture has a symbolic value in the minds of its individual representatives and gives them positive feelings and emotions. With a high prevalence of symbolism in China, it serves as a means of communication.

According to respondents, the most popular gifts in Russia are considered to be money (25\%), flowers (20\%) and sweets (12\%). In Russia, unlike China, it is acceptable to give flowers only to girls. Besides in Russia there are no are established symbolic meanings of flowers. The only limitation is the number of flowers in the bouquet (there should be only an odd number). Slightly less popular are such gifts as jewelry $(8 \%)$, perfumes $(8 \%)$, books $(6 \%)$, toys $(6 \%)$ and spirits $(6 \%)$. The least frequently there were mentioned postcards (3\%), equipment (3\%), souvenirs $(3 \%)$, socks $(2 \%)$, pens $(1 \%)$, cars $(1 \%)$, wristwatches $(1 \%)$ and phones $(1 \%)$. As one can see, the most popular gifts are impersonal in Russia.

Most Chinese would prefer to give flowers to their Russian friend which accounts for $31 \%$ of the total amount of responses. This is followed by chocolate $(12.5 \%)$ and tea $(12.5 \%)$. The custom of presenting tea in China is due to the fact that a tea tree is a symbol of fidelity because 
any attempt to transplant an adult tea tree fails. In ancient times, the groom gave tea to his bride during formal marriage proposal as a sign of the steadfastness of his words. Furthermore, tea is the symbol of fertility. The answer "a souvenir" won $9 \%$ of the total; the money occupies $6 \%$, and a Chinese knot, a cake, a calendar, spirits, clothes, shoes, jewelry, perfume or any gift scored $3 \%$ out of $100 \%$.

Choosing a gift for a friend from China, the majority of Russians (52.7\%) would have opted for a souvenir that would symbolize Russia (matryoshka, Cheburashka, fork). The respondents answered that such a gift would be associated with Russia and remind of the time spent there. $11 \%$ of the total responses are foods chocolate, national dishes, etc. The book, which is the most preferred gift among the Chinese, is about $8 \%$. There also was mentioned a set for calligraphy, a wristwatch, a pen, money, flowers, intangible gifts (a city tour, an outing), a set of wizards and vodka, which scored $2.7 \%$.

As can be seen from the analysis of the responses, the representatives of the target countries chose different gifts which they present for different purposes. The Chinese prefer flowers, for, as stated above, flowers are a way of transmitting messages and paying attention. Meanwhile the Russians chose a souvenir which is associated with time spent in Russia - a universal gift for a foreigner which does not lose its relevance over time.

According to vocabulary interpretations, a present in China is a symbol of attention and respect, while in Russia it is usually functional in nature: the association experiment confirmed these statements.

The second part of the questionnaire consists of three questions-situations with multiplechoice.

In the situation where the Chinese were asked to choose for a Russian girl a bouquet of flowers consisting of 5 roses, 2 carnations or 4 gladioli, $66 \%$ of the Chinese respondents chose the option of " 5 roses", $25 \%$ would present 2 carnations and about $8 \%$ preferred 4 gladioli. In China a carnation does not have a negative connection with a funeral procession; it is a symbol of gratitude, which cannot be said about Russia. It is also important to note that in some countries of the East, including China, it is appropriate to give even number of flowers. Consequently, as $33 \%$ of respondents would present an even number of flowers and $25 \%$ of them would prefer carnations, it can be assumed that the communication in these cases would not be successful.

In the next situation the Chinese people were to choose a birthday gift to a Russian friend. The choice was between a set of handkerchiefs, a purse with coins and wristwatches. According to the survey, most Chinese would prefer to give watches $-44 \%$ of the respondents. To give a wristwatch in Russia is considered a bad omen as it is associated with separation, while in China it is considered a good and popular gift. $32 \%$ of the answers were the option "a purse with coins". As it was mentioned above, to give money in China is considered to be the wish of wealth and prosperity. The remaining $24 \%$ of the Chinese would prefer to present a set of handkerchiefs. According to Russian tradition, a gift by way of handkerchiefs promises tears. This situation once again demonstrates that $68 \%$ of people would make a communicative mistake.

The Chinese were asked to find a way out of the situation when they cannot attend the birthday celebration of their Russian friend; therefore, they have no chance to give a gift on time. $92 \%$ of respondents chose the option "to give a gift in advance" and the remaining $8 \%$ preferred "to give a gift on arrival". Based on these data, it can be assumed that the overwhelming majority of the Chinese would made a communicative mistake as 
in Russia giving presents to somebody before the date of birth is a bad sign foreshadowing death.

If the Russians wanted to present flowers to a Chinese girl on her birthday, two thirds of them would choose gladioli and chrysanthemums (34\%), the remaining third (32\%) would chose roses. However, in China it is not acceptable to give chrysanthemums on birthday, March 8 or the Teacher's Day. Moreover, traditional flowers for a funeral there are white or yellow chrysanthemums. But roses and gladiolus have positive connotations, and therefore, they are a good gift. Consequently, the probability of conflict is about $34 \%$.

$71 \%$ of Russians believe that the Chinese would be delighted with a gift by way of an umbrella as umbrella means protection from evil spirits, and the remaining $29 \%$ believe that, on the contrary, the Chinese would be upset because umbrella means separation. Indeed, they believe that such a gift promises separation due to the fact that the word 傘 (umbrella, săn) pronounced 散 (separate, săn). Caused by this belief, the failure of cross-cultural communication could take place in $71 \%$ of cases.

Choosing a gift for Chinese New Year for a Chinese friend, $84.2 \%$ of Russians would choose a live orange tree. Indeed, this fruit is considered as a symbol of good luck and immortality. To present a live orange tree or its fruit is an ancient tradition in China, meaning a wish of happiness, wealth and success. $13.1 \%$ of respondents chose 400 yuan in a red envelope. In China they gift money in a red envelope on the New Year holiday, but the number 4 has a negative connotation. The thing is that the Chinese a numeral "four" (四, sì) and a verb “to die" (死, sǐ) are homophones, so this number is undesirable in any form. The option "set of knives" was chosen by $2.6 \%$ of respondents. As in China the gifts in the form of sharp objects mean strained relations, a conflict is probable to occur in $16 \%$ of cases out of $100 \%$.

\section{Conclusion}

This study allows reaching a number of conclusions.

"Concept" is a mental formation which replaces in the process of thinking an indefinite multitude of objects, actions, mental functions of the same kind. It arises from the combination of the individual's educational level, professional, social and personal experiences. For the most accurate description of the concept in the minds of people, the methods of associative experiment and questionnaires are used.

The main lexeme, verbalizing the "gift" concept in the Chinese language is 礼物, which means "gift" and "present". It is an act of courtesy and a measure of friendly intentions. In Russian, a "gift" is what is presented. It is not only something tangible; it may be a joyful event and a treat. The material value of the gift is not a priority for both the Chinese and Russians. For them it is much more important whose present it is and what symbolic meaning it expresses.

Universal characteristics of the "gift" concept in China and Russia are the following. Firstly, a gift is what is presented; secondly, the concept has positive connotations; thirdly, giving a present to somebody is a unique way of expressing emotions.

Several features of the "gift" concept may be considered specific to the Chinese culture. They are the purposes of giving a gift which are to pay tribute, to show good or friendly intentions, etc. Then comes the lack of the figurative meaning of the word "gift" in the dictionaries of the Chinese language. The Chinese people pay more attention to emotions related to the donation and acceptance of the gift, to the symbolic meaning of it and to the rituals and ceremonies of making a present. They often associate gifts with different celebrations and meetings with friends. Sometimes there can be traced a negative attitude to gifts in connection with bribes and selfish intent. 
There are some culturally-specific apologize and win the goodwill of people by features of the "gift" concept in Russia too. First of all, they are the objectives designated giving presents.

In view of the differences in cultural practices in the dictionaries such as to please someone by giving him/her a present or do good to someone. In the Russian language the word "gift" can be interpreted as something very nice, something affording pleasure. Gifts are often appreciated in terms of their practicality. The Russians are inclined to there is a high risk of making communication errors both by the Chinese and the Russians during intercultural interaction. According to the data received with the help of the questionnaire, such interaction may end in failure through the fault of the Chinese in $68 \%$ of cases, and the fault of the Russians in $26 \%$ of all cases.

\section{References}

Askol'dov, S.A. (1997). Kontsept i slovo [A concept and a word]. In Russkaya slovesnost. Ot teorii slovesnosti $k$ strukture teksta. Antologiya [The Russian philology. From the theory of words to the text srtructure. Antology]. Moscow, Academia, 267-279 p.

Biyazdykova, A.A., Nurpeiys, T.A. and Baimuhanbetova, M.B. (2014). The Studying of the "Happiness" Concept in the Kazakh Language. In Middle-East Journal of Scientific Research. 19 (5), $712-715$.

Chikogu, R.N. (2009). Power in politeness. A pragmatic study of the linguistic concept of politeness and change in social relations of power in Wole Soyinka's The Beatification of Area. In English Text Construction, 2 (1), 70-90.

Gunina, N.A. (2011). Concept vs. meaning: Cognitive approach. In Vestnik TSTU, 17 (1), available at: vestnik.tstu.ru>rus/t_17/pdf/17_1_032.pdf

Karasik, V.I., Slyshkin, G.G. (2001). Lingvokulturnyiy kontsept kak edinitsa issledovaniya. Metodologicheskie problemyi kognitivnoy lingvistiki [Lingvocultural concept as an object of study. Methodological problems of cognitive linguistics]. In Sbornik nauchnikh trudov [Collection of research papers], 1, 75-80 (Voronezh: VGU).

Kardash, K.A. (2016). Actants and circonstants in the semantic situation "Congratulation" in the Chinese literary texts and its translations. In Journal of Siberian Federal University. Humanities and Social Sciences, 9 (3), 637-645.

Manerko, L. (2014). Concept understanding in cognitive linguistics and cognitive terminology science. In Languages for Special Purposes in a Multilingual, Transcultural World, Proceedings of the $19^{\text {th }}$ European Symposium on Languages for Special Purposes, 8-10 July 2013, Vienna, 471-483.

Stepanov, J.S. (2007). Kontseptyi. Tonkaya plenka tsivilizatsii [Concepts. A thin membrane of civilization]. Moscow, Yazyiki slavyanskih kultur, 248 p.

Tovbaz, A.A., Chibisova, O.V. (2012). The concept of "Luck" in Russian and Chinese songs. In Uspekhi sovremennogo estestvoznaniya, 5, 35.

Türkey, E. (2013). A corpus-based approach to emotion metaphors in Korean. A case study of anger, happiness, and sadness. In Review of Cognitive Linguistics, 11(1), 73-144.

Vasil'eva, A., Chibisova, O. (2015). Semantic variability of the "gift" concept in the Chinese and Russian lingvocultures. In Moral potential of the society: reproduction preservation and intensification issues 2nd edition: research articles, 80-84. 


\title{
Концепт «подарок» в индивидуальном сознании \\ русских и китайщев
}

\author{
А.А. Васильева, О.В. Чибисова \\ Комсомольский-на-Амуре государственньй \\ университет \\ Россия, 681013, Комсомольск-на-Амуре, \\ пр. Ленина, 27
}

\begin{abstract}
Данная статья основана на социолингвистических и культурологических исследованиях теоретических и практических вопросов изучения конщептов. Актуальность данного исследования подтверждается недостаточным отражением концепта «подарок» в существующих научных трудах. Подарок является очень важной составляющей социального взаимодействия как в бизнесе, так и в быту. На фоне активно развиваюшихся международных отношений Китая и России изучение русского и китайского национальных характеров и культур имеет практическое значение для специалистов, осуществляющих международные связи Китая и России. Данная статья представляет собой сравнительньий анализ ассоциаций русских и китайцев к концепту «подарок», что и позволяет выявить национально-специфические и культурно-универсальные черты в их семантике. Знание данных особенностей поможет коммуникантам преодолеть барьер взаимного непонимания.
\end{abstract}

Ключевые слова: конџепт, подарок, социальная и межкультурная коммуникация.

Научная специальность: 10.00.00 - филологические науки. 